\title{
Q
}

\section{Doing Rights with Things: The Art of Becoming Citizens}

\author{
Engin Isin
}

\section{Performativity, Performance, Enactment}

An origin of performativity is often traced back to J. L. Austin (1962) and the controversy that followed with Jacques Derrida's (1988) intervention on its uses by John Searle (1970), and the subsequent uptake of the perspective by Shoshana Felman (2003), Judith Butler (1990, 1997), Eve Sedgwick (2003), and others. This particular trajectory has been well illustrated by James Loxley (2007) (see also Moati 2014). Yet, as I mentioned, performativity has multiple origins and crisscrossing trajectories in philosophy (Mulligan 1987; Reinach 1983), sociology (Goffman 1967, 1961, 1959; Tilly 2008), anthropology (Turner 1966, 1987), and humanities, which led to the emergence of performance studies (Schechner 2002; Davis 2008). As one would expect from a performative perspective, the meaning and uses of performativity and performance were multiple, conflicting, and dynamic (Lloyd 2016). And its uses also involved invoking traditions of thought that may not have used performativity, but its affiliate principles (Youdell 2006).

E. Isin $(\bowtie)$

Queen Mary University of London, London, UK

e-mail: engin.isin@qmul.ac.uk

(C) The Author(s) 2019

P. Hildebrandt et al. (eds.), Performing Citizenship, Performance

Philosophy, https://doi.org/10.1007/978-3-319-97502-3_4 
Another origin of performativity is traced to theories of enactment in philosophy (Edie 1971; Ware 1973; Deutscher 1988) and cognitive sciences (Zarrilli 2007; Stewart et al. 2010). The concept of acts has been especially prominent in this trajectory for understanding social and political conduct (Pluth 2007; Perinbanayagam 1985). So 'enactment' has come to acquire a special meaning, to determine the conditions under which social acts occur and the kinds of people or things that such enactments produce (Mol 2003; Law and Urry 2011).

Given these multiple and complex origins and trajectories of the development of a performative perspective in social sciences and humanities, I do not intend to discuss its meanings and uses here. Without giving in to the temptation to singularize, I would still say that in all these origins, trajectories, and developments, performativity is an attempt to understand the ways in which people inhabit and transform specific subjectivities and how these subjectivities follow from acts that are made possible only under certain material and symbolic conditions. Or, as Michel Foucault put it, a concern in social sciences and humanities is to understand 'how should one "govern oneself" by performing actions in which one is oneself the objective of those actions, the domain in which they are brought to bear, the instrument they employ, and the subject that acts?' (Foucault 1997, p. 87). If social sciences and humanities in the nineteenth and twentieth centuries struggled over tensions between agency and structure, or objectivity and subjectivity, it is perhaps not a coincidence that, in the twentyfirst century, some scholars are drawn to a performative perspective where understanding people as acting beings in their objective and subjective circumstances involves a dramaturgical language where words such as stages, scenes, acts, performances, actors, and sites that provide a rich repertoire (Rayner 1994) and a performative language where words such citations, iterations, and significations provide a means by which to understand how we inhabit identities, practices, and selves (Nakassis 2013; Holywood 2002).

There are various tensions in using these dramaturgical and performative languages and between performance and performativity. Austin famously excluded speech acts performed on stage from his analysis and thought that these were not ordinary uses of language. He thought that 'a performative utterance will, for example, be in a peculiar way hollow or void if said by an actor on the stage, or if introduced in a poem, or spoken in soliloquy' (Austin 1962, p. 22). This was precisely what Derrida took issue with, questioning a difference between words spoken in literature 
and ordinary life as though they belonged to separate serious and 'playful' uses of words. He was emphatic:

for, ultimately, isn't it true that what Austin excludes as anomaly, exception, 'non-serious,' citation (on stage, in a poem, or a soliloquy) is the determined modification of a general citationality-or rather, a general iterability - without which there would not even be a 'successful' performative? So that - a paradoxical but unavoidable conclusion-a successful performative is necessarily an 'impure' performative, to adopt the word advanced later on by Austin when he acknowledges that there is no 'pure' performative. (Derrida 1988, p. 17)

Derrida certainly made it difficult to maintain a pure difference between ordinary and literary language, and also between languages of arts, sciences, and politics.

We are now witnessing the increasing use of these dramaturgical and performative languages in understanding how people inhabit citizenship as political subjectivity, and how citizenship is enacted in everyday acts with or without authorization to act under its (legal) prescription (Isin 2017). Both in social sciences and humanities, there are now many contemporary (Ofer and Groves 2016; McThomas 2016) and historical (Farenga 2006; Prauscello 2014) studies that use a performative perspective on citizenship. I want to broadly reflect on how 'performing citizenship' is proving a useful perspective for scholars and how they are making a productive use of it. What I want to discuss below is not various uses of performativity and performance in studying citizenship but to outline a logic of their use: how the need for such a perspective has arisen and how it is challenging our views of citizenship.

\section{What Is Called Citizenship?}

Citizenship mediates the relations between the citizen, non-citizens, and polities to which they belong, claim, or inhabit. That simple statement always belies the fact that the citizen of a polity almost never belongs only to that polity but to several nested, if not overlapping and conflicting, series of polities, like the city, region, the state, and the international. Clearly, in the contemporary world, the sovereign polity is the state, but even its sovereignty is now implicated in various international and regional polities evinced by international covenants (such as the European 
Convention of Human Rights), multilateral agreements (like the North American Free Trade Agreement), supranational bodies (as in the European Union), and shared sovereignty arrangements (for example, Scotland or Quebec). This is further complicated by the fact that many citizens and non-citizens in the contemporary world do not reside in their birthplace but in - often multiple - adopted countries. All this places citizens and non-citizens as relational subjects within a web of rights and responsibilities, through which they are called upon to performatively negotiate a particular combination that is always a complex relationship.

A Chinese government cannot have a unified and singular relationship with its citizens since their lives are mediated not only through their rights from and responsibilities to the Chinese state but also through human rights, environmental or cultural discourse, and international politics beyond its borders. Similarly, a British government cannot have exclusive relations with British citizens, as their lives are implicated in and interdependent with the European Union as a supranational polity, the European Convention of Human Rights, and myriad other mutual rights and responsibilities toward other polities. Even if the British government decides to end its membership of the European Union, there would still be a web of obligations and commitments that would implicate its citizens and non-citizens. While still dominant, the state therefore cannot be said to have an exclusive sovereignty over a given population within a given territory.

It is then problematic to think about citizenship as a universal, static, and enclosed relationship, as Iris Young (1989) argued in a brilliant and now classic article. We can observe today that the combination between rights and responsibilities is always an outcome of social struggles that find expression in political and legal institutions in different polities. Three conventional rights (civil, political, and social) and three responsibilities (conscription, taxation and participation) define the relationship between the citizen and the state. Civil rights include the right to free speech, to conscience, and to dignity; political rights include franchise and standing for office; social rights include unemployment insurance, universal health care, and welfare. Although conscription is rapidly disappearing as a responsibility of citizenship, taxation remains resolutely in place; jury duty is increasingly challenged under certain circumstances, but still serves a fundamental role. Moreover, new rights have appeared-such as sexual rights, cultural rights, and environmental rights-with varying degrees of success in institutionalization (for example, witness the struggles over 
same-sex marriage in the United States and Europe). Again, as mentioned, whether conventional (that is, civil, political, social) or expanded (sexual, environmental, cultural), these rights and responsibilities are mediated through other polities that influence the actual combination granted in a given polity at a given time.

Conventional perspectives on citizenship (such as liberalism, republicanism, and communitarianism) make much less sense now, given the contemporary complications just mentioned. Since the combination of rights and responsibilities, and their performance, greatly varies across polities it is probably more accurate to speak about various citizenship regimes that characterize a similar, if not co-dependent, development of certain combinations. We can, for example, talk about an Anglo-American regime (for example, Britain, USA), a North European regime (such as Denmark, Norway), a continental regime (such as France, Germany), a South American regime (such as Brazil, Chile), a South Asian regime (such as India, Malaysia), and so forth. We can also talk about postcolonial citizenship regimes (for example, India, Brazil, Ghana), post-communist citizenship regimes (such as Poland, Hungary, and even China), neoliberal citizenship regimes (such as Britain, USA), and post-settler citizenship regimes (such as Canada, Australia). Arguably, each of these regimes sets out a different combination of rights and responsibilities of citizenship, but each displays a recognizable culture with regard to how citizenship is performed.

Yet, in each of these polities, citizenship does not exist in a singular and unified form either. There are struggles over its meaning in courts, education, services, taxation, and many other spheres of life. How we approach citizenship in our contemporary world is then a complex question because, as James Tully (2014) argued, we inherit not single but multiple, overlapping, and conflicting uses of institutions, laws, and traditions that use the word 'citizenship'. He warns against defining a meaning that is ostensibly universal while attempting to apply it to different circumstances. He identifies an attitude within this desire, for example, in the attribution of a universal meaning such as 'modern' and an attitude that desires to see it as 'diverse' as 'critical'. A modern attitude is marked by its will to develop citizenship as a civil code and a critical attitude is marked by seeing citizenship as a negotiated and dynamic relationship (Tully 2014, pp. 5-8). For Tully, the challenge to be found in citizenship is in identifying its diverse forms in different places, yet maintaining a productive language about the ways in which we speak and write about it. Tully draws on Wittgenstein, 
who was also a source of inspiration for Austin. Although Tully does not use the language of performativity, his use of words-such as games, enactment, and play-to understand citizenship as negotiated practices, strongly resonates with performativity; or at least it shows a logic as to why scholars are increasingly drawn into a dramaturgical language in the face of its practical complexities.

\section{Doing Rights with Things}

This increasing use of dramaturgical and performative languages-such as 'performing citizenship', 'enacting citizenship', or 'acts of citizenship'by scholars recognizes two key aspects of citizenship. First, that there is a recognition that citizenship that exists on paper is an expression of inert or passive rights, yet citizenship rights (and responsibilities) are brought into being only when performed. It is not only that rights that have been won through long and hard social struggles (such as freedom of speech or social insurance) would disappear if not performed, but also that such struggles require performing rights that may not exist (for example, sexual rights, animal rights, or ecological rights). Second, since citizenship is brought into being by performing it, non-citizens can also perform citizenship. The political subjects - individual or collective - of citizenship are not given in advance, they too are brought into being performatively. Those who do not have the status of citizenship, but obtain it by making claims to it, often negotiate many rights and responsibilities. These two performative aspects of citizenship have often been recognized by studies that examine tensions or gaps between different articulations of citizenship in public discourse.

These two aspects of performing citizenship permeate social and political life more than meets the eye. When people mobilize for legalizing same-sex marriage, rally for social housing, protest against welfare cuts, debate employment insurance, sign petitions, occupy squares, advocate the decriminalization of marijuana, apply for citizenship, renounce their citizenship, wear attire such as turbans or headscarves in public spaces, seek affirmative action programs, demand better health care access and services, or practice their graffiti art across borders, they may not express themselves as struggling for the maintenance or expansion of social, cultural, or sexual citizenship rights. Governments may not recognize them as such either. Instead, people invest in whatever issues seem most related and closest to their social and political lives—and dedicate their time and 
energy accordingly - and governments respond, or fail to respond, to these demands. There are two points to make about such struggles. First, they are irreducibly political struggles that arise from social, economic or cultural conditions in which people are situated. To classify such struggles either as redistribution (economism) or recognition (culturalism) misses their complexity. Second, in the absence of clear articulation, it is important to acknowledge that when people enact themselves through such performances or acts-whatever differences may separate them in values, principles, and priorities - they are performing citizenship, even those who are not passport-carrying members of the state (non-citizens). This means that they are being playful, creative, and innovative in drawing upon various repertories of becoming or unbecoming citizens.

I would like to propose formalizing these points by naming different senses in which citizenship exists. I think citizenship is performed or played in the gaps or tensions between and among these different senses of citizenship. There is, for example, citizenship (in) theory. This is where contestations over the meanings, functions, and uses of citizenship take place. There may be statements about ideas of universal, egalitarian, fairness concerns around citizenship. There may be normative or positive claims to represent citizenship. These senses of citizenship (in) theory often struggle and contest with each other over these meanings and functions of citizenship. There is then citizenship (in) practice, where people uptake or inhabit citizenship through rituals, habits, manners, and gestures. People vote, protest, petition, and pay (or avoid or evade) their taxes. We can then also speak about citizenship (in) law where it is codified, enforced, and revised. There is then citizenship (in) acts where it is resisted, revoked, deprived, claimed, demanded, and so forth. These different senses in which citizenship exists are not mutually exclusive, but interrelated senses that come into conflict with each other. A citizenship that is advocated (in) theory may well fall short of what transpires in law and how citizenship (in) practice comes to function may confront citizenship (in) law. Citizenship (in) acts may disrupt what we do with citizenship (in) practice.

I think citizenship (in) theory, citizenship (in) practice, and citizenship (in) law signify different senses of citizenship in the following ways: the dramas played out in courts and legislatures for citizenship (in) law find their counterparts on streets, squares, assemblies, and cyberspaces of citizenship (in) practice. These dramas are played out no less intensely in articles, books, and conferences; developing citizenship (in) theory rather 
than in elections, referendums, and plebiscites of citizenship (in) acts. Although these plays mediate between citizens and polities, performing citizenship does not always take the form of demands on government. To put it differently, performing citizenship always involves a citizenship-asyet-to-come. If Austin characterized performativity as doing things with words, it is tempting to describe performativity of citizenship as 'doing rights with things' to emphasize not only the actual social and political struggles that mobilize it, but also practical, material, artistic, expressive, and articulate ways in which people enact citizenship on a stage that may or may not be of their choosing.

These may provide us with some reasons why scholars are drawn to a performative perspective on citizenship. As Mary McThomas argues, for example, to make sense of the struggles of undocumented migrants requires an understanding of the tensions between citizenship (in) law and citizenship (in) practice. This is because, she asserts, 'a performance-based conception of citizenship, which focuses on the carrying out of civic duties instead of nation-state authorization, more accurately reflects our current situation and recognizes obligations we have to those living among us' (2016, p. 2). She illustrates that, in the USA, there is a disconnection between 'paper citizenship and performing citizenship, [which] expose[s] the gap between the reality of our neighborhoods and conventional theories of citizenship and political obligation' (2016, p. 37). She argues that instead of understanding obligation to be what citizens owe to the state, we should flip it and ask 'what the state owes to those who perform the role of citizen, regardless of their documented status' (2016, p. 38). This resonates with many scholars with regard to undocumented migrants who have studied it as performing citizenship (Jeffers 2011; Aradau et al. 2010; McNevin 2011; Nyers 2008, 2011; Erel 2009; Squire 2016).

As Inbal Ofer and Tamar Groves (2016) and their colleagues illustrated, citizenship is being performed in social movements across the world, traversing many state borders. They argue that we are witnessing 'multiscalar dynamics: global logics and institutions reinforce local structures and channels of interventions, which generate new understandings of citizenship as a form of being and of interacting with other social groups' (Ofer and Groves 2016, p. 8). As I mentioned earlier, there are differences in the ways in which acts, enactment, performance, and performativity are used by these scholars, and yet their perspective- on how active (and activist) ways in which citizens and non-citizens become citizens on a stage of not necessarily their choosing-is common. 


\section{The Art of Becoming Citizens}

If indeed citizenship mediates the relations between citizens, non-citizens, and polities to which we belong, claim, or inhabit, then it also involves the art of being with others, negotiating different situations and identities, and articulating ourselves as distinct yet similar to others in our everyday lives. Through these social struggles, we develop a sense of our rights as others' obligations and others' rights as our obligations. As Christopher Kutz (2002) reasoned, this a collective work of citizenship. This is especially true for democratic citizenship, as it approaches the combination of rights and responsibilities as a dynamic (and thus contested, but changing and flexible) outcome and its creative performance as a key aspect within a democratic polity (Zivi 2012).

Citizenship, especially democratic citizenship, depends on the creative and organizing capacities of citizens whose performance of citizenship is not only the driving force for change but also the guarantee of the vitality and resilience of the polity. Governments may see domains of citizen performativity and enactment as separate from each other in the everyday governing of the polity and in the social lives of its citizens, but occasionally, an event reminds everyone that people (citizens and noncitizens) are performing or enacting themselves as citizens. The gapstraversed between citizenship (in) theory, citizenship (in) practice, citizenship (in) law, and citizenship (in) acts-are increasingly where articulate, effective languages of everyday politics emerge and are where literary and artistic performances are playing out serious roles. For all these reasons, a dramaturgical language, combined with a language of performativity, is proving both productive and suggestive in order to give accounts of ourselves both individually and collectively struggling as citizens and non-citizens.

\section{REFERENCES}

Aradau, Claudia, Jef Huysmans, and Vicky Squire. 2010. Acts of European Citizenship: A Political Sociology of Mobility. Journal of Common Market Studies 48 (4): 945-965.

Austin, J.L. 1962. How to Do Things with Words. Oxford: Oxford University Press. Butler, Judith. 1990. Gender Trouble: Feminism and the Subversion of Identity. London: Routledge.

- 1997. Excitable Speech: A Politics of the Performative. London: Routledge. 
Davis, Tracy C. 2008. Introduction: The Pirouette, Detour, Revolution, Deflection, Deviation, Tack, and Yaw of the Performative Turn. In The Cambridge Companion to Performance Studies, ed. Tracy C. Davis, 1-8. Cambridge, University of Cambridge Press.

Derrida, Jacques. 1988. Limited Inc. Trans. G. Graff. Evanston: Northwestern University Press.

Deutscher, Max. 1988. Simulacra, Enactment and Feeling. Philosophy 63 (246): 515-528.

Edie, James M. 1971. The Problem of Enactment. The Journal of Aesthetics and Art Criticism 29 (3): 303-318.

Erel, Umut. 2009. Migrant Women Transforming Citizenship. London: Ashgate.

Farenga, Vincent. 2006. Citizen and Selfin Ancient Greece: Individuals Performing Justice and the Law. Cambridge/New York: Cambridge University Press.

Felman, Shoshana. 2003. The Scandal of the Speaking Body: Don Juan with J.L. Austin, or Seduction in Two Languages. Stanford: Stanford University Press.

Foucault, Michel. 1997. Ethics: Subjectivity and Truth. In Essential Works of Foucault, 1954-1984, ed. P. Rabinow, vol. 3. New York: The New Press.

Goffman, Erving. 1959. The Presentation of Self in Everyday Life. Garden City: Doubleday.

- 1961. Encounters: Two Studies in the Sociology of Interaction. Indianapolis: Bobbs-Merrill.

- 1967. Interaction Ritual: Essays on Face-to-Face Behavior. Garden City: Doubleday.

Holywood, Amy. 2002. Performativity, Citationality, Ritualization. History of Religions 42: 93-115.

Isin, Engin F. 2017. Performative Citizenship. In The Oxford Handbook of Citizenship, ed. Ayelet Shachar, Rainer Bauböck, Irene Bloemraad, and Maarten Vink, 500-523. Oxford: Oxford University Press.

Jeffers, Alison. 2011. Refugees, Theatre and Crisis: Performing Global Identities. New York: Palgrave Macmillan.

Kutz, Christopher. 2002. The Collective Work of Citizenship. Legal Theory 8: 471-494.

Law, John, and John Urry. 2011. Enacting the Social. Economy and Society 33 (3): $390-410$.

Lloyd, Moya. 2016. Performativity and Performance. In The Oxford Handbook of Feminist Theory, ed. Lisa Jane Disch and M.E. Hawkesworth, 572-592. Oxford: Oxford University Press.

Loxley, James. 2007. Performativity. London: Routledge.

McNevin, Anne. 2011. Contesting Citizenship: Irregular Migrants and New Frontiers of the Political. New York: Columbia University Press.

McThomas, Mary. 2016. Performing Citizenship: Undocumented Migrants in the United States. London: Routledge. 
Moati, Raoul. 2014. Derrida/Searle: Deconstruction and Ordinary Language. Trans. Timothy Attanucci, and Maureen Chun. New York: Columbia University Press.

Mol, Annemarie. 2003. The Body Multiple: Ontology in Medical Practice. Durham: Duke University Press.

Mulligan, Kevin, ed. 1987. Speech Act and Sachverhalt: Reinach and the Foundations of Realist Phenomenology. Dordrecht: Kluwer Academic Publishers.

Nakassis, Constantine V. 2013. Citation and Citationality. Signs and Society l (1): $51-77$.

Nyers, Peter. 2008. In Solitary, in Solidarity: Detainees, Hostages and Contesting the Anti-Policy of Detention. European Journal of Cultural Studies 11: 333-349.

-2011. No One Is Illegal Between City and Nation. Studies in Social Justice 4: 127-143.

Ofer, Inbal, and Tamar Groves, eds. 2016. Performing Citizenship: Social Movements Across the Globe. London: Routledge.

Perinbanayagam, R.S. 1985. Signifying Acts: Structure and Meaning in Everyday Life. Carbondale: Southern Illinois University Press.

Pluth, Ed. 2007. Signifiers and Acts: Freedom in Lacan's Theory of the Subject. Albany: State University of New York Press.

Prauscello, Lucia. 2014. Performing Citizenship in Plato's Laws. Cambridge: Cambridge University Press.

Rayner, Alice. 1994. To Act, to Do, to Perform: Drama and the Phenomenology of Action. Ann Arbor: University of Michigan Press.

Reinach, Adolf. 1983. The Apriori Foundations of the Civil Law. Trans. John Crosby in a special issue of Aletheia 3: 1-142 (original edn. 1913).

Schechner, Richard. 2002. Performance Studies: An Introduction. London: Routledge.

Searle, John R. 1970. Speech Acts: An Essay in the Philosophy of Language. Cambridge: Cambridge University Press.

Sedgwick, Eve Kosofsky. 2003. Touching Feeling: Affect, Pedagogy, Performativity. Durham: Duke University Press.

Squire, Vicki. 2016. Unauthorised Migration Beyond Structure/Agency Acts, Interventions, Effects. Politics: 1-19.

Stewart, John Robert, Olivier Gapenne, and Ezequiel A. Di Paolo, eds. 2010. Enaction: Toward a New Paradigm for Cognitive Science. Cambridge, MA: MIT Press.

Tilly, Charles. 2008. Contentious Performances. Cambridge: Cambridge University Press.

Tully, James. 2014. On Global Citizenship: James Tully in Dialogue. London: Bloomsbury. 
Turner, Victor Witter. 1966. The Ritual Process: Structure and Anti-Structure. New York: Aldine de Gruyter. 1987. The Anthropology of Performance. New York: PAJ Publications.

Ware, Robert. 1973. Acts and Action. The Journal of Philosophy 70: 403-418.

Youdell, Deborah. 2006. Subjectivation and Performative Politics: Butler Thinking Althusser and Foucault: Intelligibility, Agency and the Raced-NationedReligioned Subjects of Education. British Journal of Sociology of Education 27 (4): $511-528$.

Young, Iris Marion. 1989. Polity and Group Difference: A Critique of the Ideal of Universal Citizenship. Ethics 99 (2): 250-274.

Zarrilli, Phillip B. 2007. An Enactive Approach to Understanding Acting. Theatre Journal 59 (4): 635-647.

Zivi, Karen. 2012. Making Rights Claims: A Practice of Democratic Citizenship. Oxford: Oxford University Press.

Open Access This chapter is licensed under the terms of the Creative Commons Attribution 4.0 International License (http://creativecommons.org/licenses/ by $/ 4.0 /$ ), which permits use, sharing, adaptation, distribution and reproduction in any medium or format, as long as you give appropriate credit to the original author(s) and the source, provide a link to the Creative Commons licence and indicate if changes were made.

The images or other third party material in this chapter are included in the chapter's Creative Commons licence, unless indicated otherwise in a credit line to the material. If material is not included in the chapter's Creative Commons licence and your intended use is not permitted by statutory regulation or exceeds the permitted use, you will need to obtain permission directly from the copyright holder.

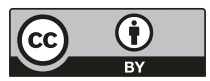

